\title{
Studies on Keeping Quality of Preserved Guava Pulp during Storage
}

\author{
Suman Kumari Yadav ${ }^{1}$, D.K. Sarolia ${ }^{2}$, Shalini Pilania ${ }^{1}$, H.R. Meena ${ }^{3 *}$ and L.N. Mahawer $^{1}$ \\ ${ }^{1}$ Department of Horticulture, RCA, MPUAT, Udaipur (Rajasthan), India \\ ${ }^{2}$ Division of crop Production, ICAR- CIAH, Bikaner (Rajasthan), India \\ ${ }^{3}$ ICAR- IISWC, Research Centre, Kota (Rajasthan), India \\ *Corresponding author
}

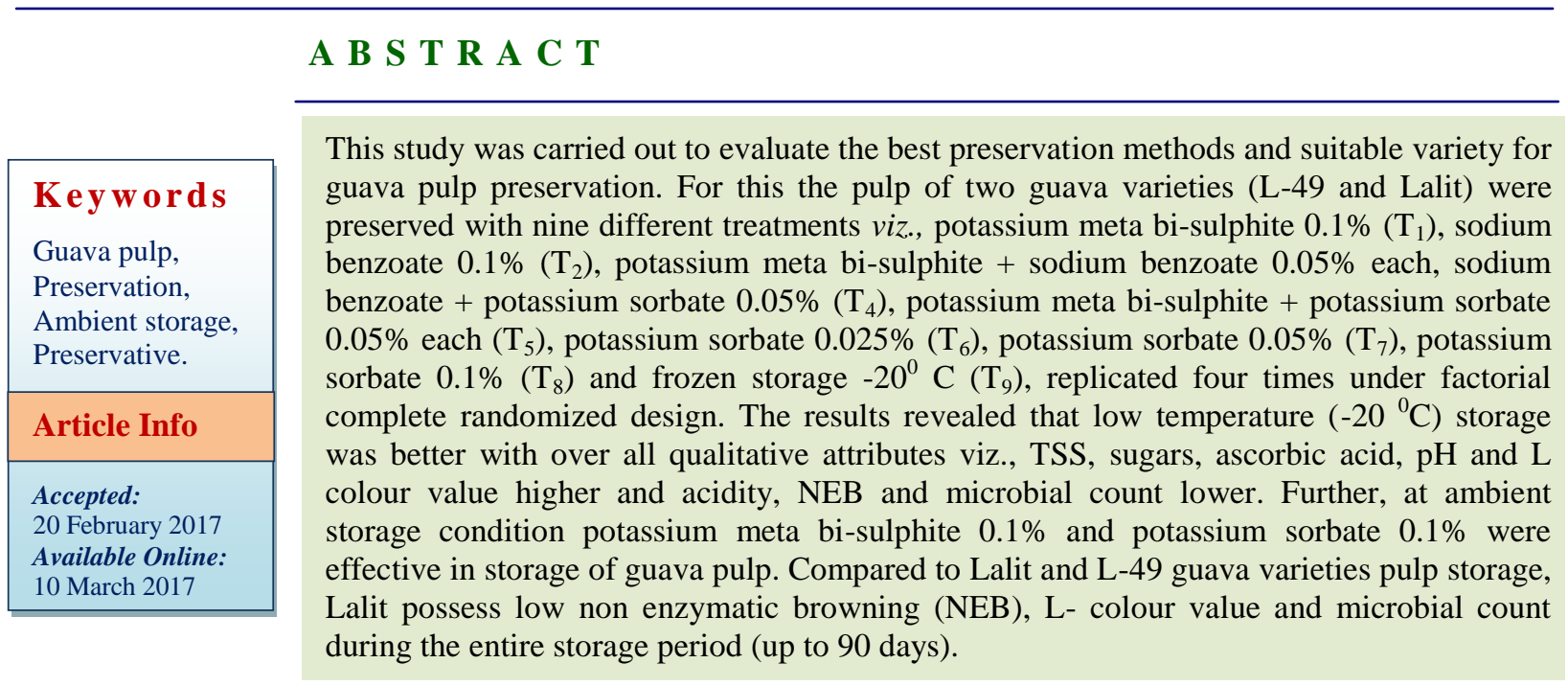

\section{Introduction}

Guava (Psidium guajava L.) is one of the most exquisite, nutritionally valuable and remunerative fruit of the tropics and belongs to the family "Myrtaceae". Guava is also called the "Apple of Tropics" and "Poor man's apple". Guava is quite hardy, prolific bearer and highly remunerative even without much care. It is widely grown all over the tropics and sub-tropics including India. Fruit consist of 20 per cent peel, 50 per cent flesh and remaining portion as seed core (Wilson, 1980). Guava fruit normally consumed as fresh as a dessert fruit due to excellent flavour, high digestive and nutritive value, high palatability and availability in abundance of guava fruits show great potential for processing into valuable products, which have nutritional as well as health benefits. It's a better option for further use to make number of processed products such as nectar, squash, clarified juice, concentrates, canned, dehydrated powder, jam, RTS, cheese and blends with other juices. Surplus produce use in processing of fruit into various products is one of the best ways to reduce post harvest losses (Bons et al., 2013).

Guava tree bears two crops during rainy and winter season in sub tropics. Guava tree has tendency to bear maximum crop during rainy 
season. This crop is poor in quality and the fruit are rough, insipid, watery and less nutritive. Rainy season fruits are also spoiled rapidly due to loss of glossy appearance with discoloration followed by blemishes, desiccation, loss of firmness and vitamin $\mathrm{C}$ after harvest. Rainy season fruits owing to high perishability, less storability (not more that 3 days) and poor taste restrict its consumption as a fresh fruit in this season and farmers' could not get reasonable price of their produce. The post harvest losses occurs about 22 per cent (Bons and Dhawan, 2006). Therefore, need of the hour to use this rainy season crop through stored in form of pulp to increase its availability over an extended period and to stabilize the price during glut season and can be further utilize for preparation of various value added products. Keeping this in view the present experiment was conducted.

\section{Materials and Methods}

The experiment was carried out in the Fruit and Vegetable processing lab, Department of Horticulture, Rajasthan College of Agriculture, MPUAT, Udaipur (Raj.) during the year July, 2015 to November, 2015. Fully mature and ripe guava cv. Lalit and L-49 fruits were procured from horticulture farm. The pulp was extracted by hot method $\left(90^{\circ} \mathrm{C}\right)$. Obtained pulp was preserved with nine different treatments namely, potassium meta bi-sulphite $0.1 \%\left(\mathrm{~T}_{1}\right)$, sodium benzoate $0.1 \%$ $\left(\mathrm{T}_{2}\right)$, potassium meta bi-sulphite + sodium benzoate $0.05 \%$ each, sodium benzoate + potassium sorbate $0.05 \%\left(\mathrm{~T}_{4}\right)$, potassium meta bi-sulphite + potassium sorbate $0.05 \%$ each $\left(\mathrm{T}_{5}\right)$, potassium sorbate $0.025 \%\left(\mathrm{~T}_{6}\right)$, potassium sorbate $0.05 \%\left(\mathrm{~T}_{7}\right)$, potassium sorbate $0.1 \%\left(\mathrm{~T}_{8}\right)$ and frozen storage $-20^{\circ} \mathrm{C}$ $\left(\mathrm{T}_{9}\right)$ and replicated four times with two units. Physico-chemicals parameters of samples were observed at 0, 30, 60, 90 days of storage. The TSS content of pulp was directly measured by the "Digital Refractometer" (Brix: 0.0 to $53.0 \%$ ) at $20^{\circ} \mathrm{C}$ temperature. Ascorbic acid by 2,6-dichlorophenol indophenols dye method and acidity content of pulp was determined by diluting the known volume of pulp with distilled water and titrating the same against standard N/10 sodium hydroxide solution, using phenolphthalein as an indicator (A.O.A.C., 1995). Reducing sugars was measured by following "DNS Method" (Miller, 1959). Total Sugar was estimated by using "Anthrone Method" (Dubois et al., 1951). The $\mathrm{pH}$ of the pulp was directly measured on the $\mathrm{pH}$ meter. The non-enzymatic browning (NEB) in the pulp was determined by measuring optical density (OD) of methanol extracts of samples at $440 \mathrm{~nm}$ in UV-VIS spectrophotometer (Labomed Inc., USA). Numbers of bacteria were counted by using Thornton's medium and fungi were counted by using martin's Rose-Bengal medium. The data were analysed by using Factorial completely randomized design (Fisher, 1950).

\section{Results and Discussion}

\section{TSS and total sugar}

It is evident from the data (Table 1) that TSS and total sugar content of stored guava pulp was increased with the advancement of storage period in all the treatments. The mean maximum TSS and total sugar content were recorded in the frozen storage treatment $\mathrm{T}_{9}$ $\left(13.03^{0} \mathrm{~B}\right.$ and $\left.7.76 \%\right)$ followed by $\mathrm{T}_{1}$ $\left(12.46^{\circ} \mathrm{B}\right.$ and $\left.7.67 \%\right)$ and minimum in $\mathrm{T}_{6}$ $\left(11.78^{0} \mathrm{~B}\right.$ and $\left.7.16 \%\right)$ during the storage. The increment in TSS content of preserved guava pulp during storage was probably due to conversion of free polysaccharides (starch) into monosaccharide (Jain et al. 2007). TSS and total sugar content during storage have positive proportional trend (Desai et al., 2012 in mango pulp and Chand and Gehlot, 2006 in bael pulp). Varietal influence was also 
evident from the same table that TSS (12.55

$\left.{ }^{0} \mathrm{~B}\right)$ and total sugar $(8.00 \%)$ content of L-49 variety was higher during entire storage period over Lalit. Probably it might be due to Lalit variety comparatively contains more acidity than L-49 that maintain lower TSS content and total sugar during storage. The present study is in the agreement with Jain et al., (2007) in guava pulp and Kumar et al., (2015) in ber pulp.

\section{Acidity and pH}

The results indicate that the acidity of preserved guava pulp was increased and $\mathrm{pH}$ was decreased slightly with the advancement of storage period (Table 2). The mean maximum acidity $(0.585 \%)$ was recorded in the treatment $\mathrm{T}_{6}$ (PS@0.025\%) and minimum $(0.555 \%)$ was in the frozen storage treatment $\left(\mathrm{T}_{9}\right)$. In $\mathrm{pH}$ vice versa value was observed from acidity i.e., maximum in treatment $\mathrm{T}_{9}$ (3.99) and minimum in $\mathrm{T}_{6}$ (3.66) treatment. The increment in acidity of preserved guava pulp during storage period was due to formation of organic acids by degradation of ascorbic acids (Bal et al., 2014) and decrease in $\mathrm{pH}$ might be due to the formation of free acids and pectin hydrolysis (Ahmad et al., 2000).

Variety Lalit $(0.574 \%)$ recorded higher mean acidity and lower $\mathrm{pH}$ value (3.77) compare to the variety L-49 (0.560\% acidity and 3.89 $\mathrm{pH})$. Probably it might be due to varietal characteristics like variety Lalit contain low TSS and higher acidity compare to L-49. Present study was in the agreement with the Ahmad et al., (2000) observed that decrease in $\mathrm{pH}$ of guava pulp during storage.

\section{Ascorbic acid and reducing sugar}

Ascorbic acid content of guava pulp was decreased with advancement of storage period. The maximum ascorbic acid content was retained in treatment $\mathrm{T}_{9}$ (frozen storage)

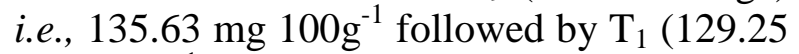
$\mathrm{mg} 100 \mathrm{~g}^{-1}$ ) and minimum in treatment $\mathrm{T}_{6}$

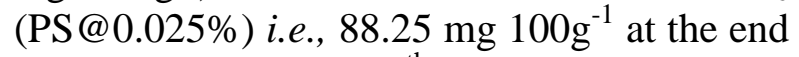
of storage period $\left(90^{\text {th }}\right.$ days). Decrease in ascorbic acid content was due to the oxidation of ascorbic acid to de hydro ascorbic acid and then further degraded to 2, 3-diketo-gluconic acid by the action of ascorbic acid oxidase enzyme.

Mean ascorbic acid contain in the variety L49 (136.91 mg $100 \mathrm{~g}^{-1}$ ) higher over Lalit (127.74 mg $100 \mathrm{~g}^{-1}$ ) throughout the storage period, but decreased with advancement of storage period in both the varieties. The present study is in the cognizance with the findings of Bons et al., (2011).

\section{Reducing sugar}

Same table also explicated that increment in reducing sugar with the advancement of storage period in all the treatments (Table 3), maximum reducing sugar content was recorded from treatment $\mathrm{T}_{9}$ (frozen storage) i.e., 6.47 per cent followed by $\mathrm{T}_{1}(6.45 \%)$ and minimum in treatment $\mathrm{T}_{6}$ (PS@0.025\%) i.e., 6.09 per cent at the end of storage days. It might be due to breakdown of some of the hemicelluloses and other saccharides into simple soluble sugars. Same table also evident that guava variety Lalit recorded significantly lower reducing sugar as compared to L-49 and their respective mean value were 4.39 and 5.14, respectively. Variety Lalit has low reducing sugar probably due to lower amount of TSS as compared to L-49 variety. The present study supported by the findings of Tandon and Kalra (1984) in guava pulp and Desai et al., (2012) in mango pulp.

\section{NEB and $L$ colour value}

NEB: Non enzymatic browning of guava pulp was increased with advancement of storage 
period. The minimum NEB was recorded in $\mathrm{T}_{9}(0.059,0.114$ and 0.238$)$ followed by $\mathrm{T}_{1}$ $(0.059,0.119$ and 0.218$)$ and maximum in treatment $\mathrm{T}_{6}(0.063,0.134$ and 0.359$)$ at 30 , 60 and $90^{\text {th }}$ days of storage. It might be due formation of furfural and its derivatives at high temperature formed by reaction of ascorbic acid with citric acid. These derivatives could have contributed to nonenzymatic browning which were higher at high temperature. Low non-enzymatic browning in treatment $T_{1}$ might be due to better antioxidant action of KMS and more non-enzymatic browning in $\mathrm{T}_{6}$ could be due to Millard and Caramelization reactions.

Same table also revealed that both variety show increasing trend in NEB with the advancement of storage period. It was recorded that NEB from L-49 was higher as compared to Lalit. At $90^{\text {th }}$ days of storage period, recorded NEB from L-49 (0.283) and from Lalit (0.252). The present study supported by Bons et al., (2013) in guava pulp and Sarolia and Mukherjee (2002) in lime juice.

\section{Colour $L^{*}$ value}

At 60 and 90 days of storage luminosity value of guava pulp was recorded maximum in $\mathrm{T}_{9}$ (43.40 and 36.44, respectively) closely followed by $\mathrm{T}_{1} \quad(41.76$ and 35.55, respectively) and minimum in $\mathrm{T}_{6}$ (37.53 and 28.22, respectively) treatment. Same table also explicated that mean luminosity $\left(L^{*}\right)$ for variety L-49 (42.71) contained higher as compared to Lalit (40.01). Luminosity of both the cultivars decreased with the advancement of storage duration due to higher non enzymatic browning showed increasing trend with the storage duration.

Table.1 Effect of preservation methods and varieties on TSS and total sugar content of guava pulp during storage

\begin{tabular}{|c|c|c|c|c|c|c|c|c|}
\hline \multirow[t]{3}{*}{ Treatments } & \multicolumn{7}{|c|}{ Storage duration (days) } & \\
\hline & \multicolumn{4}{|c|}{ TSS $\left({ }^{0} \mathrm{~B}\right)$} & \multicolumn{4}{|c|}{ Total sugar $(\%)$} \\
\hline & 30 & 60 & 90 & Mean & 30 & 60 & 90 & Mean \\
\hline \multicolumn{9}{|l|}{ Preservation methods } \\
\hline $\mathrm{T}_{1}(\mathrm{KMS}-0.1 \%)$ & 12.09 & 12.41 & 12.90 & 12.46 & 6.47 & 7.62 & 8.92 & 7.67 \\
\hline $\mathrm{T}_{2}(\mathrm{SB}-0.1 \%)$ & 11.90 & 12.24 & 12.45 & 12.19 & 6.35 & 7.50 & 8.78 & 7.54 \\
\hline $\mathrm{T}_{3}(\mathrm{SB}+\mathrm{KMS}-0.05 \%)$ & 12.06 & 12.33 & 12.65 & 12.34 & 6.44 & 7.59 & 8.89 & 7.64 \\
\hline $\mathrm{T}_{4}(\mathrm{PS}+\mathrm{SB}-0.05 \%)$ & 11.66 & 12.06 & 12.29 & 12.00 & 6.31 & 7.46 & 8.74 & 7.50 \\
\hline $\mathrm{T}_{5}(\mathrm{PS}+\mathrm{KMS}-0.05 \%)$ & 11.70 & 12.11 & 12.33 & 12.04 & 6.33 & 7.48 & 8.77 & 7.52 \\
\hline $\mathrm{T}_{6}(\mathrm{PS}-0.025 \%)$ & 11.35 & 11.94 & 12.07 & 11.78 & 6.23 & 7.08 & 8.18 & 7.16 \\
\hline $\mathrm{T}_{7}(\mathrm{PS}-0.05 \%)$ & 11.56 & 12.05 & 12.24 & 11.95 & 6.29 & 7.44 & 8.72 & 7.48 \\
\hline $\mathrm{T}_{8}(\mathrm{PS}-0.1 \%)$ & 12.00 & 12.27 & 12.53 & 12.26 & 6.39 & 7.54 & 8.85 & 7.59 \\
\hline $\mathrm{T}_{9}$ (Deep Freeze $\left(-20^{\circ} \mathrm{C}\right)$ & 12.59 & 12.91 & 13.58 & 13.02 & 6.51 & 7.76 & 9.01 & 7.76 \\
\hline C.D. $(P=0.05)$ & NS & 0.468 & 0.713 & & NS & 0.154 & 0.194 & \\
\hline \multicolumn{9}{|l|}{ Varieties } \\
\hline $\mathrm{V}_{1}$ (Lalit) & 11.62 & 11.91 & 12.19 & 11.90 & 6.15 & 6.90 & 8.18 & 7.07 \\
\hline $\mathrm{V}_{2}(\mathrm{~L}-49)$ & 12.14 & 12.60 & 12.92 & 12.55 & 6.59 & 8.09 & 9.34 & 8.00 \\
\hline C.D. $(\mathrm{P}=0.05)$ & 0.365 & 0.221 & 0.336 & & 0.106 & 0.073 & 0.091 & \\
\hline
\end{tabular}


Int.J.Curr.Microbiol.App.Sci (2017) 6(3): 1235-1242

Table.2 Effect of preservation methods and varieties on acidity and $\mathrm{pH}$ content of guava pulp during storage

\begin{tabular}{|c|c|c|c|c|c|c|c|c|}
\hline \multirow[t]{3}{*}{ Treatments } & \multicolumn{7}{|c|}{ Storage duration (days) } & \\
\hline & \multicolumn{4}{|c|}{ Acidity $(\%)$} & \multicolumn{4}{|c|}{$\mathrm{pH}$} \\
\hline & 30 & 60 & 90 & Mean & 30 & 60 & 90 & Mean \\
\hline \multicolumn{9}{|l|}{ Preservation methods } \\
\hline $\mathrm{T}_{1}(\mathrm{KMS}-0.1 \%)$ & 0.452 & 0.542 & 0.672 & 0.555 & 4.03 & 3.95 & 3.80 & 3.93 \\
\hline $\mathrm{T}_{2}(\mathrm{SB}-0.1 \%)$ & 0.460 & 0.548 & 0.697 & 0.568 & 3.94 & 3.87 & 3.82 & 3.88 \\
\hline $\mathrm{T}_{3}(\mathrm{SB}+\mathrm{KMS}-0.05 \%)$ & 0.453 & 0.545 & 0.683 & 0.560 & 3.95 & 3.91 & 3.78 & 3.88 \\
\hline $\mathrm{T}_{4}(\mathrm{PS}+\mathrm{SB}-0.05 \%)$ & 0.466 & 0.555 & 0.698 & 0.573 & 3.90 & 3.78 & 3.66 & 3.78 \\
\hline $\mathrm{T}_{5}(\mathrm{PS}+\mathrm{KMS}-0.05 \%)$ & 0.465 & 0.553 & 0.696 & 0.571 & 3.89 & 3.81 & 3.70 & 3.80 \\
\hline $\mathrm{T}_{6}(\mathrm{PS}-0.025 \%)$ & 0.472 & 0.562 & 0.722 & 0.585 & 3.76 & 3.70 & 3.52 & 3.66 \\
\hline $\mathrm{T}_{7}(\mathrm{PS}-0.05 \%)$ & 0.464 & 0.557 & 0.704 & 0.575 & 3.85 & 3.75 & 3.59 & 3.73 \\
\hline $\mathrm{T}_{8}(\mathrm{PS}-0.1 \%)$ & 0.458 & 0.547 & 0.685 & 0.563 & 3.96 & 3.87 & 3.72 & 3.85 \\
\hline $\mathrm{T}_{9}\left(\right.$ Deep Freeze $\left(-20^{\circ} \mathrm{C}\right)$ & 0.451 & 0.539 & 0.672 & 0.554 & 4.11 & 4.01 & 3.85 & 3.99 \\
\hline C.D. $(P=0.05)$ & 0.0120 & 0.0137 & 0.0242 & & 0.170 & 0.161 & 0.154 & \\
\hline \multicolumn{9}{|l|}{ Varieties } \\
\hline $\mathrm{V}_{1}$ (Lalit) & 0.465 & 0.555 & 0.703 & 0.574 & 3.88 & 3.78 & 3.64 & 3.77 \\
\hline $\mathrm{V}_{2}(\mathrm{~L}-49)$ & 0.455 & 0.544 & 0.682 & 0.560 & 3.99 & 3.92 & 3.77 & 3.89 \\
\hline C.D. $(\mathrm{P}=0.05)$ & 0.0057 & 0.0065 & 0.0114 & & 0.080 & 0.076 & 0.072 & \\
\hline
\end{tabular}

Table.3 Effect of preservation methods and varieties on ascorbic acid and reducing sugar content of guava pulp during storage

\begin{tabular}{|c|c|c|c|c|c|c|c|c|}
\hline \multirow[t]{3}{*}{ Treatments } & \multicolumn{7}{|c|}{$\begin{array}{l}\text { Storage duration (days) } \\
\end{array}$} & \\
\hline & \multicolumn{4}{|c|}{ Ascorbic acid (mg 100g $\left.\mathrm{g}^{-1}\right)$} & \multicolumn{4}{|c|}{ Reducing sugar $(\%)$} \\
\hline & 30 & 60 & 90 & Mean & 30 & 60 & 90 & Mean \\
\hline \multicolumn{9}{|l|}{ Preservation methods } \\
\hline $\mathrm{T}_{1}(\mathrm{KMS}-0.1 \%)$ & 163.00 & 149.25 & 129.25 & 147.17 & 3.34 & 4.73 & 6.45 & 4.84 \\
\hline $\mathrm{T}_{2}(\mathrm{SB}-0.1 \%)$ & 152.38 & 137.13 & 106.38 & 131.96 & 3.25 & 4.65 & 6.37 & 4.76 \\
\hline $\mathrm{T}_{3}(\mathrm{SB}+\mathrm{KMS}-0.05 \%)$ & 156.50 & 141.50 & 112.75 & 136.92 & 3.32 & 4.72 & 6.43 & 4.72 \\
\hline $\mathrm{T}_{4}(\mathrm{PS}+\mathrm{SB}-0.05 \%)$ & 145.50 & 130.50 & 100.13 & 125.38 & 3.22 & 4.64 & 6.35 & 4.74 \\
\hline $\mathrm{T}_{5}(\mathrm{PS}+\mathrm{KMS}-0.05 \%)$ & 149.38 & 134.88 & 104.63 & 129.63 & 3.23 & 4.65 & 6.36 & 4.75 \\
\hline $\mathrm{T}_{6}(\mathrm{PS}-0.025 \%)$ & 132.38 & 117.63 & 88.25 & 112.75 & 3.19 & 4.51 & 6.09 & 4.60 \\
\hline $\mathrm{T}_{7}(\mathrm{PS}-0.05 \%)$ & 140.25 & 124.75 & 97.25 & 120.75 & 3.21 & 4.63 & 6.34 & 4.73 \\
\hline $\mathrm{T}_{8}(\mathrm{PS}-0.1 \%)$ & 153.00 & 137.25 & 108.00 & 132.75 & 3.29 & 4.68 & 6.43 & 4.80 \\
\hline $\mathrm{T}_{9}$ (Deep Freeze $\left(-20^{0} \mathrm{C}\right)$ & 170.63 & 155.63 & 135.63 & 153.96 & 3.36 & 4.75 & 6.47 & 4.86 \\
\hline C.D. $(P=0.05)$ & 6.05 & 5.86 & 5.25 & & NS & 0.114 & 0.126 & \\
\hline \multicolumn{9}{|l|}{ Varieties } \\
\hline $\mathrm{V}_{1}$ (Lalit) & 147.00 & 132.00 & 104.22 & 127.74 & 3.10 & 4.11 & 5.96 & 4.39 \\
\hline $\mathrm{V}_{2}(\mathrm{~L}-49)$ & 155.67 & 141.00 & 114.06 & 136.91 & 3.44 & 5.21 & 6.77 & 5.14 \\
\hline C.D. $(\mathrm{P}=0.05)$ & 2.85 & 2.76 & 2.47 & & 0.066 & 0.054 & 0.059 & \\
\hline
\end{tabular}


Int.J.Curr.Microbiol.App.Sci (2017) 6(3): 1235-1242

Table.4 Effect of preservation methods and varieties on NEB and colour $\mathrm{L}^{*}$ value of guava pulp during storage

\begin{tabular}{|c|c|c|c|c|c|c|c|c|}
\hline \multirow[t]{3}{*}{ Treatments } & \multicolumn{7}{|c|}{ Storage duration (days) } & \\
\hline & \multicolumn{4}{|c|}{ NEB (nm) } & \multicolumn{4}{|c|}{ Colour $L^{*}$} \\
\hline & 30 & 60 & 90 & Mean & 30 & 60 & 90 & Mean \\
\hline \multicolumn{9}{|l|}{ Preservation methods } \\
\hline $\mathrm{T}_{1}(\mathrm{KMS}-0.1 \%)$ & 0.0596 & 0.1195 & 0.218 & 0.132 & 53.89 & 41.76 & 35.51 & 43.72 \\
\hline $\mathrm{T}_{2}(\mathrm{SB}-0.1 \%)$ & 0.0614 & 0.1208 & 0.259 & 0.147 & 50.97 & 39.97 & 32.97 & 41.30 \\
\hline $\mathrm{T}_{3}(\mathrm{SB}+\mathrm{KMS}-0.05 \%)$ & 0.0601 & 0.1234 & 0.233 & 0.139 & 52.16 & 41.03 & 34.28 & 42.49 \\
\hline $\mathrm{T}_{4}(\mathrm{PS}+\mathrm{SB}-0.05 \%)$ & 0.0625 & 0.1243 & 0.273 & 0.153 & 50.00 & 39.00 & 30.25 & 39.75 \\
\hline $\mathrm{T}_{5}(\mathrm{PS}+\mathrm{KMS}-0.05 \%)$ & 0.0632 & 0.1296 & 0.294 & 0.162 & 50.66 & 39.66 & 31.29 & 40.54 \\
\hline $\mathrm{T}_{6}(\mathrm{PS}-0.025 \%)$ & 0.0636 & 0.1343 & 0.359 & 0.186 & 48.53 & 37.53 & 28.22 & 38.09 \\
\hline $\mathrm{T}_{7}(\mathrm{PS}-0.05 \%)$ & 0.0635 & 0.1308 & 0.324 & 0.173 & 50.01 & 39.01 & 30.01 & 39.68 \\
\hline $\mathrm{T}_{8}(\mathrm{PS}-0.1 \%)$ & 0.0608 & 0.1233 & 0.238 & 0.141 & 51.72 & 40.72 & 33.47 & 41.97 \\
\hline $\mathrm{T}_{9}$ (Deep Freeze $\left(-20^{\circ} \mathrm{C}\right)$ & 0.0593 & 0.1144 & 0.209 & 0.128 & 54.31 & 43.40 & 36.44 & 44.72 \\
\hline C.D. $(\mathrm{P}=0.05)$ & 0.0013 & 0.0040 & 0.011 & & NS & 1.850 & 1.875 & \\
\hline \multicolumn{9}{|l|}{ Varieties } \\
\hline $\mathrm{V}_{1}$ (Lalit) & 0.0608 & 0.122 & 0.252 & 0.145 & 50.05 & 38.83 & 31.16 & 40.01 \\
\hline $\mathrm{V}_{2}(\mathrm{~L}-49)$ & 0.0623 & 0.126 & 0.283 & 0.157 & 52.67 & 41.64 & 33.82 & 42.71 \\
\hline C.D. $(\mathrm{P}=0.05)$ & 0.0006 & 0.0018 & 0.0011 & & 1.729 & 0.872 & 0.884 & \\
\hline
\end{tabular}

Table.5 Effect of preservation methods and varieties fungal and bacterial growth (cfu g-1) of guava pulp during storage

\begin{tabular}{|c|c|c|c|c|c|c|c|c|}
\hline \multirow[t]{3}{*}{ Treatments } & \multicolumn{7}{|c|}{ Storage duration (days) } & \\
\hline & \multicolumn{4}{|c|}{ Fungus (cfu X $\left.10^{4} \mathrm{~g}^{-1}\right)$} & \multicolumn{4}{|c|}{ Bacteria $\left(\mathrm{cfu} \times 10^{6} \mathrm{~g}^{-1}\right)$} \\
\hline & 30 & 60 & 90 & Mean & 30 & 60 & 90 & Mean \\
\hline \multicolumn{9}{|l|}{ Preservation methods } \\
\hline $\mathrm{T}_{1}(\mathrm{KMS}-0.1 \%)$ & 1.6 & 2.5 & 4.7 & 2.9 & 1.5 & 2.2 & 3.8 & 2.5 \\
\hline $\mathrm{T}_{2}(\mathrm{SB}-0.1 \%)$ & 1.7 & 3.9 & 5.8 & 3.8 & 1.7 & 3.0 & 4.6 & 3.1 \\
\hline $\mathrm{T}_{3}(\mathrm{SB}+\mathrm{KMS}-0.05 \%)$ & 3.1 & 5.3 & 8.0 & 5.5 & 2.4 & 3.8 & 6.1 & 4.1 \\
\hline $\mathrm{T}_{4}(\mathrm{PS}+\mathrm{SB}-0.05 \%)$ & 2.5 & 4.1 & 6.5 & 4.4 & 2.0 & 3.1 & 5.0 & 3.4 \\
\hline $\mathrm{T}_{5}(\mathrm{PS}+\mathrm{KMS}-0.05 \%)$ & 2.7 & 4.6 & 7.0 & 4.8 & 2.1 & 3.6 & 5.6 & 3.8 \\
\hline $\mathrm{T}_{6}(\mathrm{PS}-0.025 \%)$ & 3.4 & 6.3 & 9.4 & 6.4 & 2.7 & 5.2 & 8.0 & 5.3 \\
\hline $\mathrm{T}_{7}(\mathrm{PS}-0.05 \%)$ & 3.1 & 6.3 & 8.8 & 6.1 & 2.3 & 4.8 & 7.3 & 4.3 \\
\hline $\mathrm{T}_{8}(\mathrm{PS}-0.1 \%)$ & 2.0 & 3.1 & 5.3 & 3.5 & 1.6 & 2.7 & 4.1 & 2.8 \\
\hline $\mathrm{T}_{9}$ (Deep Freeze $\left(-20^{\circ} \mathrm{C}\right)$ & 1.7 & 2.5 & 4.1 & 2.8 & 1.5 & 2.0 & 3.3 & 2.3 \\
\hline C.D. $(\mathrm{P}=0.05)$ & 2.20 & 2.07 & 3.69 & & 0.73 & 1.52 & 2.08 & \\
\hline \multicolumn{9}{|l|}{ Varieties } \\
\hline $\mathrm{V}_{1}$ (Lalit) & 2.3 & 4.2 & 6.4 & 4.3 & 1.9 & 3.2 & 5.2 & 3.4 \\
\hline$V_{2}(L-49)$ & 2.5 & 4.3 & 6.7 & 4.5 & 2.0 & 3.4 & 5.3 & 3.6 \\
\hline C.D. $(\mathrm{P}=0.05)$ & 1.04 & 0.97 & 1.74 & & 0.34 & 0.72 & 0.98 & \\
\hline
\end{tabular}




\section{Microbial counts}

Total fungal and bacterial growth in preserved guava pulp was increased with the advancement of storage period (Table 5). The maximum fungal growth was recorded in the treatment $\mathrm{T}_{6}$ (PS@0.025\%) i.e., 9.4 and minimum was in the frozen storage treatment $\left(\mathrm{T}_{9}\right)$ i.e., 4.1. In bacterial growth same trend was observed maximum in treatment $\mathrm{T}_{6}(5.3)$ and minimum in $\mathrm{T}_{9}(2.3)$ treatment.

It can't be stopped but can be inhibit by using preservatives. Sodium benzoate and potassium meta bi- sulphite (KMS) are most commonly used for long term storage as they have show better antimicrobial activity (Sofos et al., 1981; Mangnelli et al., 1983; Luck et al., 1990). The present study was in agreement with Ayub et al., (2010) in strawberry juice and Khattak et al., (2014) in apricot pulp.

Variety L-49 recorded higher mean fungal and bacterial growth i.e., 4.5 and 3.6, respectively while Lalit recorded minimum mean fungal and bacterial growth i.e., 4.3 and 3.4 , respectively. The probable reason might be due to Lalit variety relatively acidic with low $\mathrm{pH}$ compare to L-49 that suppresses the fungal and bacterial growth. The present study supported by Akhtar et al., (2010) in mango pulp.

Thus, guava pulp preservation under low temperature $\left(-20^{\circ} \mathrm{C}\right)$ gave superior quality and better storage life during the storage but in economic point of view preservative potassium meta bi sulphite @ $0.1 \%$ followed by potassium sorbate @ $0.1 \%$ may be used for the same at ambient temperature $(32+4$ $\left.{ }^{0} \mathrm{C}\right)$.

\section{References}

A.O.A.C. 1995. Official Methods of Analysis of Association of Official Analytical
Chemists, Washinton, D.C., 16: 37.

Ahmad, I., Khan, R. and Muhammad, A. 2000.Effect of added sugar at various concentrations on the storage stability of guava pulp. Sarhad J. Agri., 16(1): 8993.

Akhtar, A., Riaz, M., Ahmad, A. and Nisar, A. 2010.Physico-chemical, microbiological and sensory stability of chemically preserved mango pulp. Pak. J. Bot., 42(2): 853-862.

Ayub, M., Ullah, J., Muhammad, A. and Zeb, A. 2010. Evaluation of strawberry juice preserved with chemical preservatives at refrigeration temperature. Int. $J$. Nutrition and Metabolism, 2(2): 27-32.

Bal, L.M., Ahmad, T., Senapati, A.K. and Pandit, P.S. 2014. Evaluation of quality attribute during storage of guava nectar cv. Lalit from different pulp and TSS ratio. J. Food Processing and Technol., 5(5): 329-334.

Bons, H., Dhawan, S.S. and Mahajan. 2011. Effect of chemical preservatives and heating on preservation of guava pulp at low temperature. Crop Res., 42(1,2 and 3): $148-150$.

Bons, H.K. and Dhawan, S.S. 2006. Effect of heating/freezing with added chemical preservatives on pulp preservation of guava (Psidiumguajava L.). Haryana $J$. Horticulture Sci., 35: 22-25.

Bons, H.K. and Dhawan, S.S. 2013. Studies on preservation of guava pulp. Indian $J$. Horticulture, 70(3): 452-454.

Chand, T. and Gehlot, R. 2006.Utilization of bael (Aeglemarmelos Correa.) for preparation and preservation of pulp. Res. Crops, 7(3):887-890.

Desai, C.S., Naik, A.K. and Patil, J.M. 2012. Study on physiochemical properties of some early mango (Mangiferaindica L) varieties for pulp processing. Beverages and Food World, 39(2): 55-57.

Fisher, R.A. 1950. Statiatical Methods for Research Workers, Oliver and Boyd. 
Edinburgh.

Jain, P.K. and Nema, P.K. 2007. Processing of pulp of various cultivars of guava (Psidiumguajava $\quad$ L.) for leather production. Agri. Engi. Int., The International council of Large Electric system, 9: 1-9.

Khattak, J.Z.K., Hussain, A., Ahmad, B., Rehman, M.F., Ullah, Z., Arshad, H. and Hussain, A. 2014. Microbiological stability of chemically preserved apricot pulp. Advancements in Life Sci., 1(3): 153-159.

Kumar, M., Godara, R.K., Singh, D., Pathak, D.V. and Singh, S. 2015. Effect of different preservatives on the storage of ber pulp. Int. J. Farm Sci., 5(4): 222228.

Luck, E. 1990. Food applications of sorbic acid and its salts. Food Additives and Contaminants, 7: 711-715.

Manganelli, E. and Casolari, A.
1983. Sensitivity of yeasts to sorbic and benzoic acids and their salts. Industria Conserve, 58: 23-25.

Miller, G.L. 1959. Determination of reducing sugar using 3, 5, Dinitrosalyclic acid. Anal. Chem., 31: 459.

Sarolia, D.K. and Mukharjee, S.K. 2002. Comparative efficacy of different preservation methods in keeping quality of lime juice during storage. Haryana $J$. Horticulture Sci., 31: 185-188.

Sofos, J. and Busta, F. 1981. Antimicrobial activity of sorbate (Mostly yeasts and molds). J. Food Protectio, 44: 614-622.

Tandon, D.K and Kalra, S.K. 1984. Chemical evaluation of stored guava pulp in polyethylene pouches. Indian Food Packeri, 38: 57-59.

Wilson, C.W. 1980. Tropical and Sub-tropical Fruits: composition, properties and uses. AVI publishing Inc West port Connecticut, 25(2): 279-295.

\section{How to cite this article:}

Suman Kumari Yadav, D.K. Sarolia, Shalini Pilania, H.R. Meena and L.N. Mahawer. 2017. Studies on Keeping Quality of Preserved Guava Pulp during Storage. Int.J.Curr.Microbiol.App.Sci. 6(3): 1235-1242. doi: https://doi.org/10.20546/ijcmas.2017.603.142 